\title{
A NEW SPECIES OF CORYDALUS (NEUROPTERA) ${ }^{1}$
}

\author{
By Nathan Banks \\ Holliston, Mass.
}

Corydalus ecuadorianus sp. nov.

Head and pronotum nearly black; meso-and metanotum rather paler, pleura nearly black; legs brown to yellowish brown, bases of tibiæ paler; abdomen black above, only a little paler beneath; antennæ black beyond the first few rufous joints; vertex with the smooth areas showing reddish as in cornuta, but reddish instead of yellowish; the smooth areas on pronotum, however, are scarcely paler than rest of surface.

Fore wing heavily marked with dark brown to black, much broken up by pale and whitish areas, rarely round, mostly irregular; cross-veins black; costal area brown on basal half, but each cell has some pale in it, beyond the costal area is largely pale with black cross-veins, some bordered; behind there are some pale spots in nearly every cell, the largest between the medius and its branch, and two pale bands in the cell behind it, two in radial area toward tip are also fairly large, and an elongate one in radial area beyond the first radial cross-vein; also one behind the origin of radial sector and reaching across the medius.

The hind wing is dark gray to brownish, but the apical half mostly brown, with black cross-veins, a square pale spot between second and third radial cross-veins, and a pale stretch in the subcostal area beyond, paler than in fore wing. Fore wing with about forty costals, in basal part several are curved, connected, or forked; the crossvein from lower medius to cubitus is continuous with that from cubitus to eubital fork. In hind wing the first radial cross-vein (very oblique as in fore wing) ends at origin of second branch of radial sector, thus forming an $X$, and the second radial cross-vein does the same with the

1 Published with a grant from the Museum of Comparative Zoölogy at Harvard College. 
fifth branch of radial sector (this doubtless varies, but not seen in any other species).

Mandibles of female short, stout, the teeth short and blunt, the tip, however, rather long and slender; the lateral carina back of antenna and eye is very indistinct; the margin of clypeus is scarcely produced in the middle, the lateral teeth being more prominent; the marginal tooth behind the eye is small and sharp; the posterior ocelli are nearly round and two diameters apart, anterior ocellus rather small; the pronotum is a little shorter than in many species, and not much broadened behind.

Length of fore wing $65 \mathrm{~mm}$., width $19.5 \mathrm{~mm}$.

One female from Banos, Ecuador, August (MacIntyre), Type M.C.Z. No. 26020.

A handsome species, and the first one from South America with the head-scars showing. 

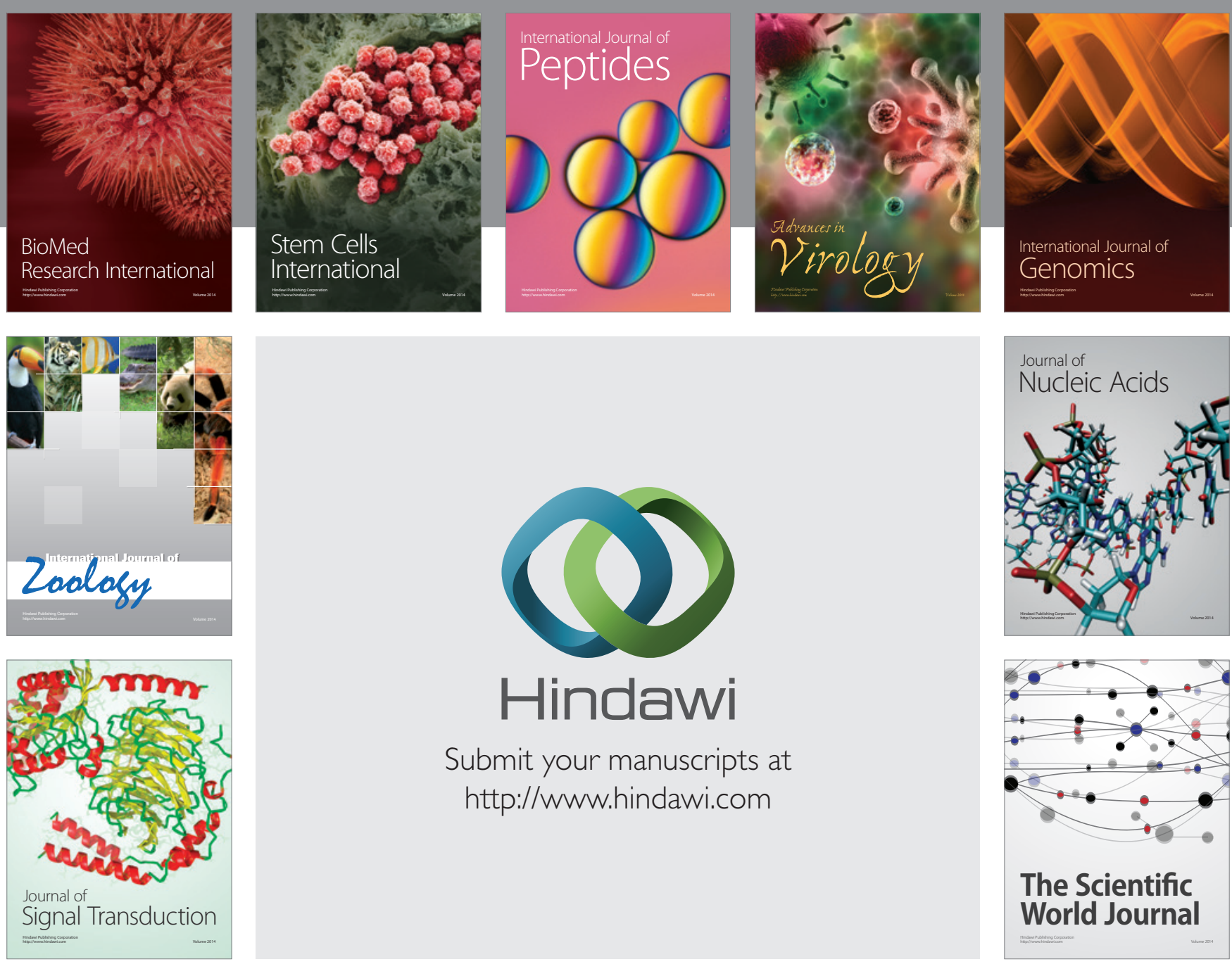

Submit your manuscripts at

http://www.hindawi.com
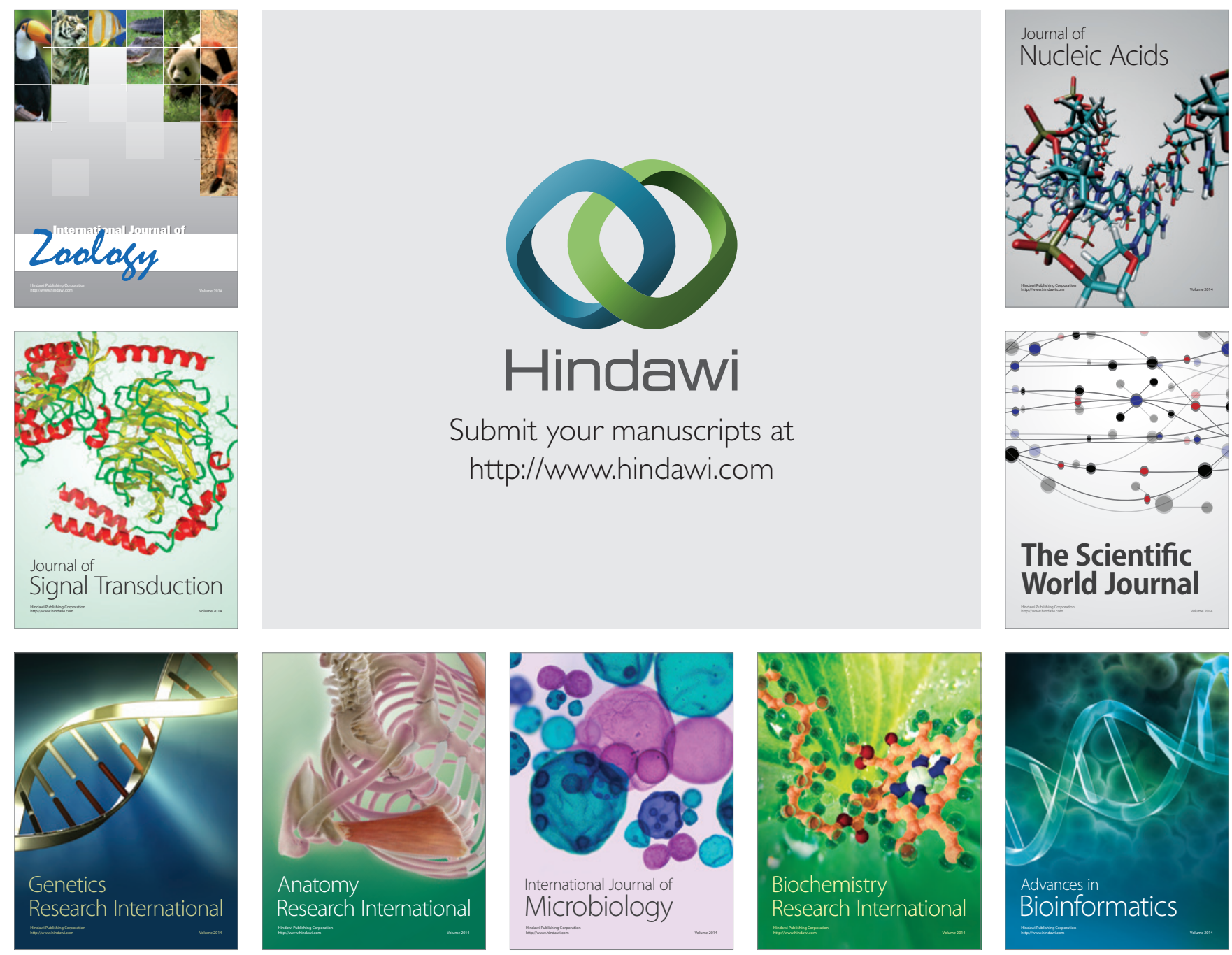

The Scientific World Journal
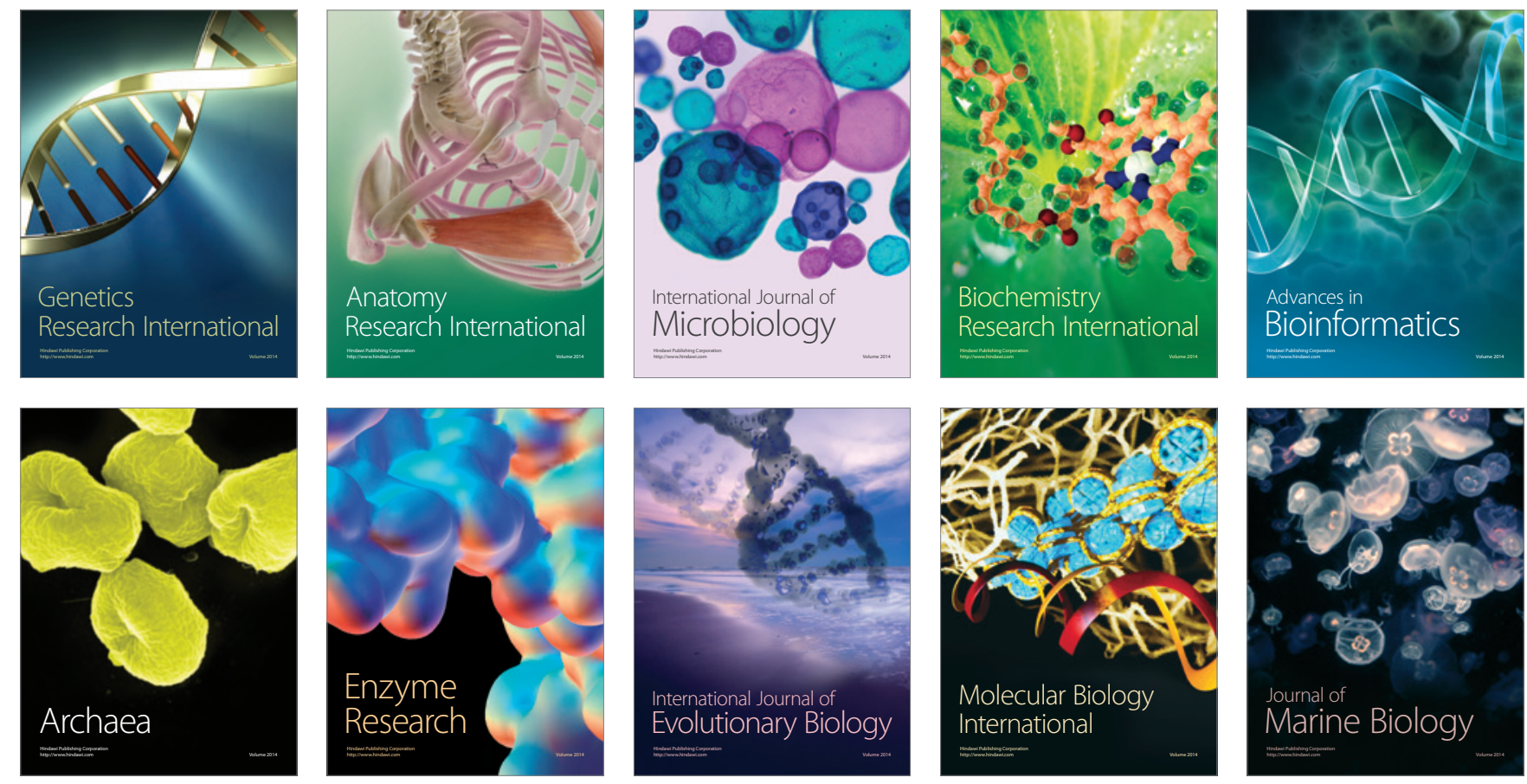